Dharma Raflesia : Jurnal Ilmiah Pengembangan dan Penerapan IPTEKS 18 (1) 2020

\title{
PELATIHAN METODE PERKALIAN ALTERNATIF BAGI GURU SD N 10 PONDOK KELAPA
}

\section{THE TRAINING OF ALTERNATIVE MULTIPLE METHODS FOR TEACHERS IN SD N 10 PONDOK KELAPA}

\author{
Oleh: \\ Nurul Astuty Yensy \\ Universitas Bengkulu \\ nurulastutyyensy@unib.ac.id
}

\begin{abstract}
ABSTRACK
Sebagian besar guru di SD N 10 Pondok Kelapa, Bengkulu Tengah masih kesulitan mengatur keberhasilan pembelajaran, terutama pembelajaran matematika. Berdasarkan studi awal, ditemukan bahwa pembelajaran yang diselenggarakan oleh guru matematika di SD 10 Pondok Kelapa masih bersifat tradisional, yaitu metode ceramah. Guru jarang menggunakan strategi pembelajaran alternatif, khususnya dalam subjek operasi multiplikasi bilangan bulat. Meskipun banyak metode alternatif perkalian yang menyenangkan, seperti metode multiplikasi latis, jadi dalam kegiatan ini "Pelatihan metode beragam alternatif untuk guru di SD N 10 Pondok Kelapa" meliputi: Seminar, Demonstrasi, pertanyaan dan jawaban, diskusi, tugas terpandu, pemantauan dan penilaian. Para guru di SD N 10 Pondok kelapa awalnya tidak memiliki pengetahuan tentang metode multiplikasi latis dalam mata pelajaran matematika dasar (100 persen). Setelah lokakarya diadakan dan setelah kegiatan praktis menyelesaikan pertanyaan penggandaan ratusan dan ribuan angka asli selesai, para guru sudah memiliki pengetahuan yang baik dan pemahaman tentang metode multiplikasi latis, secara umum respons guru terhadap kegiatan ini sangat baik. (positif) dan pengetahuan serta keterampilan mereka tentang metode multiplikasi latis sebagai metode multiplikasi alternatif semakin meningkat.
\end{abstract}

Kata kunci: Metode Alternatif, Metode Multiplikasi Latis

\begin{abstract}
Most teachers in SD N 10 Pondok Kelapa, Bengkulu Tengah still have trouble organizing successful learning, especially learning mathematics. Based on the initial study, it was found that the learning organized by mathematics teachers in SD 10 Pondok Kelapa was still traditional in nature, namely the method of lecture. Teachers rarely use the alternative learning strategies, particularly in the subject of integer multiplication operations. Although many alternative methods of multiplication are fun, such as the latis multiplication method, so in this activity the "Training of alternative multiple methods for teachers in SD N 10 Pondok Kelapa" includes: Seminars, Demonstrations, questions and answers, discussions, guided assignments, monitoring and assessment. The teachers at SD N 10 Pondok kelapa initially didn't have knowledge of the latis multiplication method in the subjects of elementary mathematics (100 per cent). After the workshop was held and after the practical activities of solving multiplication questions of hundreds and thousands of original numbers were finished, the teachers already had good knowledge and understanding of the method of latis multiplication, in general the teacher's response to this activity was very good (positive) and their knowledge and skills about the latis multiplication method as an alternative multiplication method are increasing.
\end{abstract}

Keywords: Alternative Methods Latis Multiplication Method. 
Dharma Raflesia : Jurnal Ilmiah Pengembangan dan Penerapan IPTEKS 18 (1) 2020

\section{PENDAHULUAN}

Matematika merupakan salah satu bidang studi yang ada pada semua jenjang pendidikan, mulai dari tingkat sekolah dasar hingga perguruan tinggi. Bahkan matematika diajarkan di taman kanak-kanak secara informal (Susanto, 2013). Namun, matematika merupakan salah satu pelajaran yang dianggap sulit dan membuat pusing bagi sebagian besar siswa, khususnya siswa di Sekolah Dasar. Dengan demikian, pengajaran matematika di tingkat sekolah dasar hendaknya lebih mendapat perhatian yang serius karena merupakan dasar dari pembelajaran matematika dan terjadi pada saat sekolah dasar (Yensy, NA: 2017).

Selanjutnya Matematika dasar diberikan pada jenjang pendidikan dasar karena jenjang ini merupakan pondasi yang sangat menentukan dalam membentuk sikap serta skill anak yang bermanfaat bagi kehidupan selanjutnya (Yensy, NA: 2018). Kegiatan proses pembelajaran mengharapkan setiap siswa belajar ada manfaatnya dan pembelajaran mereka bermakna, namun kenyataan menunjukkan pelajaran matematika sulit bagi siswa. Banyak siswa terkendala dalam belajar matematika, ini akibat dari proses pembelajaran tidak menarik, dan membosankan. Hal ini secara langsung sangat berpengaruh terhadap prestasi belajar matematika pada setiap jenjang pendidikan.

Matematika merupakan pengetahuan yang ada di dalam kehidupan sehari-hari. Matematika dapat memberikan pengalaman belajar yang sangat bermanfaat untuk kelangsungan hidup di masa depan. Sebagaimana pendapat Muhsetyo (2007: 1.26) bahwa pembelajaran matematika adalah proses pemberian pengalaman belajar kepada peserta didik melalui serangkaian kegiatan yang terencana sehingga peserta didik memperoleh kompetensi tentang bahan matematika yang dipelajari. Selanjutnya Matematika perlu diberikan kepada siswa untuk membekali mereka agar memiliki kemampuan berpikir logis, analitis, sistematis, kritis dan kreatif. Matematika mempunyai peranan yang penting dalam proses berpikir siswa, terutama dalam pembentukan kemampuan menganalisis, melakukan evaluasi hingga memecahkan masalah. Salah satu kemampuan yang harus dikuasai siswa dengan belajar matematika adalah memahami konsep. Kenyataan di lapangan menunjukkan bahwa kemampuan ini kurang terasah dengan baik. Sebagian siswa masih menganggap pelajaran matematika sulit dan merupakan masalah dalam proses belajarnya. Ini dapat 
Dharma Raflesia : Jurnal Ilmiah Pengembangan dan Penerapan IPTEKS 18 (1) 2020

disebabkan dari karakteristik matematika sendiri bahwa matematika bersifat abstrak, sehingga siswa membutuhkan kemampuan bernalar yang cukup untuk memahami matematika (Yensy, NA: 2019).

Hasil penelitian terdahulu menunjukkan bahwa banyaknya siswa-siswi yang tidak bisa operasi perkalian bilangan asli, bahkan perkalian bilangan asli satuan mereka tidak hafal. Sehingga hal ini menghambat dalam proses kegiatan belajar mengajar matematika. Konsep operasi perkalian bilangan asli adalah materi matematika tingkat dasar, bahkan ketika TK siswa sudah diperkenalkan. Tetapi masih banyak guru menggunakan metode hafalan dalam mengajarkan konsep operasi perkalian, sehingga konsep operasi perkalian tidak dapat dipahami siswa dengan baik. Akibatnya siswa cepat lupa dalam mengoperasikan bilangan asli. Untuk bilangan asli puluhan dan ratusan, guru cenderung menerapkan metode perkalian bersusun, tidak ada variasi metode yang lain (Marzuki, 2011).

Banyak sekali metode perkalian bilangan asli, diantaranya adalah metode jarimatika, metode perkalian bersusun, metode perkalian latis, metode sempoa dan sebagainya. Salah satu metode yang menarik adalah metode perkalian latis. Metode perkalian Latis adalah metode perkalian yang disajikan dalam bentuk tabel yang memuat hasil perkalian. Hasil perkalian dua bilangan ditempatkan dalam tabel yang disusun berdasarkan satuan, puluhan, ratusan dan seterusnya. Metode latis sangat berbeda sekali dengan metode perkalian bersusun, dimana nilai sudah ditempatkan dalam kotak tertentu sehingga mengurangi tingkat kesalahan siswa dalam operasi perkalian bilangan asli. Untuk itu, metode perkalian latis merupakan suatu metode alternatif yang dapat diberikan kepada siswa. Khususnya bagi siswa yang mengalami kesulitan dalam operasi perkalian bilangan asli puluhan dan ratusan di tingkat sekolah dasar.

Berdasarkan survei awal di SD N 10 Pondok Kelapa Kabupaten Bengkulu Tengah, lebih dari 50\% siswa kelas $\mathrm{V}$ masih mengalami kesulitan menggunakan metode perkalian bersusun. Mereka seringkali lupa cara mengoperasikan bilangan asli. Selain itu, Guru di sekolah juga belum pernah menerapkan metode lain selain metode bersusun pada operasi perkalian. Padahal secara kuantitatif, jumlah guru di SD N 10 Pondok Kelapa Benteng cukup memadai, yaitu sekitar 17 orang guru. 
Dharma Raflesia : Jurnal Ilmiah Pengembangan dan Penerapan IPTEKS 18 (1) 2020

Berdasarkan latar belakang tersebut maka dilakukan kegiatan sosialisasi kepada guru-guru di SD N 10 Pondok Kelapa tentang penggunaan metode perkalian Latis sebagai metode alternatif yang menyenangkan bagi siswa SD dalam melakukan operasi perkalian bilangan asli selain dengan menggunakan metode bersusun yang lazim diajarkan ke siswa.

\section{METODE PENGABDIAN}

Metode pelaksanaan pengabdian yang dilakukan adalah sebagai berikut:

1. Metode ceramah

Metode ini digunakan untuk memberikan pengetahuan kepada guru-guru SD N 10 Pondok Kelapa tentang berbagai metode perkalian alternatif

2. Metode Demonstrasi

Metode demonstrasi pada kegiatan ini menjelaskan langsung disertai praktik kepada guru-guru SD tentang bagaimana cara penerapan metode perkalian alternatif seperti metode latis dan penyelesaian soal-soal.

3. Pengerjaan Tugas Terbimbing

Metode ini digunakan untuk mengetahui sejauh mana pemahaman guru-guru SD tentang penerapan metode perkalian alternatif dan kemampuan dalam menyelesaikan soal- soal.

4. Metode Diskusi dan Tanya Jawab

Metode diskusi dan tanya jawab dilakukan sebagai bentuk interaksi antara peserta dan instruktur. Metode ini bertujuan untuk membantu peserta dalam menerapkan metode perkalian alternatif pada penyelesaian soal-soal. Diskusi dan tanya jawab berlangsung selama kegiatan seminar, demonstrasi dan penugasan. Metode diskusi juga digunakan untuk memberikan kesempatan kepada peserta pelatihan untuk mendalami, mengembangkan, dan menyamakan persepsi tentang penerapan metode latis.

5. Monitoring dan Evaluasi

Metode monitoring digunakan untuk mengetahui apakah peserta pelatihan menerapkan pengetahuan dan keterampilan tentang metode latis sebagai metode perkalian alternatif di sekolah mereka setelah mengikuti kegiatan pelatihan ini. 
Dharma Raflesia : Jurnal Ilmiah Pengembangan dan Penerapan IPTEKS 18 (1) 2020

Selama berlangsungnya kegiatan pelatihan dilakukan kegiatan pengamatan dengan menggunakan pedoman pengamatan, yaitu untuk mengetahui apakah kegiatan pelatihan berlangsung sesuai dengan rencana dan untuk mengetahui respon peserta terhadap kegiatan pelatihan.

Kegiatan pelatihan ini dikatakan berhasil, jika terjadi perubahan tingkah laku peserta pelatihan dari segi pengetahuan dan keterampilan tentang metode latis yang ditandai dengan:

a. Kemampuan peserta pelatihan menyampaikan metode latis sebagai metode perkalian alternatif kepada siswa, yang ditandai dengan meningkatnya pemahaman siswa pada penerapan perkalian bilangan bulat.

b. Kemampuan peserta pelatihan dalam menerapkan metode latis pada penyelesaian soal-soal.

c. Respon peserta terhadap kegiatan pelatihan ini adalah baik (peserta yang memberikan respon positif $\geq 80 \%$ ).

Peserta pelatihan terdiri dari guru-guru SD N 10 Pondok Kelapa. SD ini terletak yaitu lebih kurang $7 \mathrm{~km}$ dari lokasi UNIB.

\section{HASIL DAN PEMBAHASAN}

Rusefendi dalam Marifah (2014) mengatakan bahwa matematika adalah pola berpikir, pola mengorganisasi, pembuktian yang logis, matematika itu bahasa yang menggunakan istilah yang didefinisikan dengan cermat, jelas dan akurat, representasinya dengan simbol dan padat, lebih berupa bahasa simbol mengenai ide daripada mengenai bunyi. Hudoyo dalam Marifah (2014) mengemukakan bahwa hakikat matematika berkenan dengan ide-ide, struktur- struktur dan hubunganhubungannya yang diatur menurut urutan yang logis. Jadi matematika berkenaan dengan konsep-konsep yang abstrak. Matematika merupakan ilmu pengetahuan yang mempelajari struktur yang abstrak dan pola hubungan yang ada di dalamnya. Ini berarti bahwa belajar matematika pada hakekatnya adalah belajar konsep, struktur konsep dan mencari hubungan antar konsep dan strukturnya. Selanjutnya materi pembelajaran adalah segala sesuatu yang dibahas dalam pembelajaran dalam rangka mencapai tujuan yang telah ditetapkan. Pembelajaran matematika adalah serangkaian kegiatan belajar siswa dalam pelajaran matematika untuk mencapai tujuan yang telah 
Dharma Raflesia : Jurnal Ilmiah Pengembangan dan Penerapan IPTEKS 18 (1) 2020

ditetapkan. Tujuan umum pembelajaran matematika di SD yaitu agar siswa terampil dalam menggunakan berbagai konsep matematika. Tujuan khusus pembelajaran matematika di SD itu agar siswa memahami dan menggunakan sifat-sifat operasi hitung khususnya operasi hitung perkalian dua angka dengan dua angka yang merupakan kompetensi dasar yang baru bagi siswa kelas III sehingga kemampuan dasar melakukan operasi hitung perkalian dikuasai oleh siswa.

Metode perkalian yang lazim digunakan di tingkat SD adalah metode perkalian bersusun (Lynn \& Bellevue (2011)) yang akan dijelaskan sebagai berikut:

\section{Metode perkalian bersusun}

Berikut contoh perkalian bersusun yang lazim diberikan di sekolah dasar:

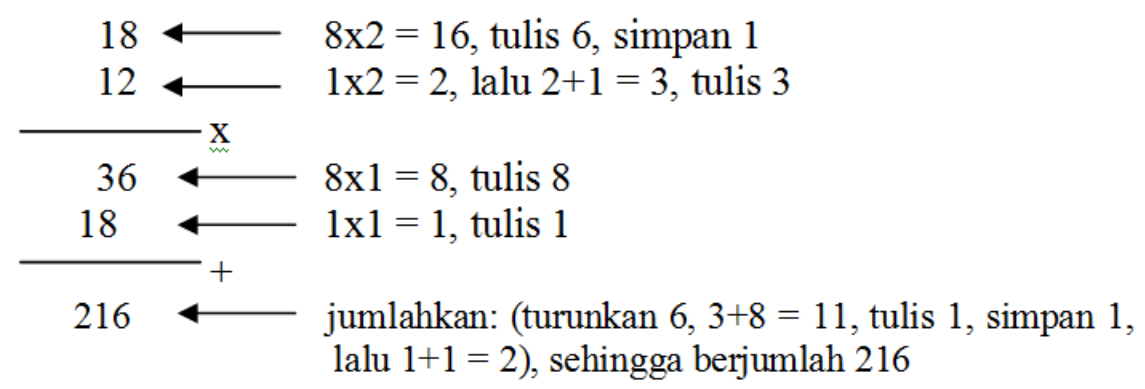

Jadi, $18 \times 12=216$

Contoh lain perkalian metode bersusun adalah sebagai berikut:

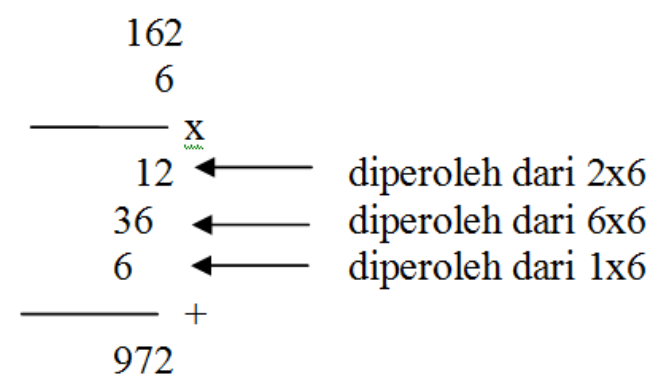

Jadi, $162 \times 6=972$

Berdasarkan kedua contoh perkalian metode bersusun di atas, terlihat bahwa secara konsep siswa harus menguasai penjumlahan bersusun terlebih dahulu, yaitu nilai satuan ditambah dengan nilai satuan, nilai puluhan ditambah dengan nilai 
Dharma Raflesia : Jurnal Ilmiah Pengembangan dan Penerapan IPTEKS 18 (1) 2020

puluhan, dan nilai ratusan ditambah dengan nilai ratusan. Misalnya pada contoh yang kedua di atas hasil perkaliannya adalah 972. Hal ini dapat dijelaskan sebagai berikut:

$012=0($ ratusan $)+10($ puluhan $)+2($ satuan $)$,

$360=300($ ratusan $)+60($ puluhan $)+0$ (satuan $)$,

$600=600($ ratusan $)+0($ puluhan $)+0($ satuan $)$

Sehingga hasilnya adalah $(0+300+600=900)$ sebagai nilai tempat ratusan, lalu $(10$ $+60+0=70)$ sebagai nilai tempat puluhan, dan $(2+0+0=2)$ sebagai nilai tempat satuan.

Dengan demikian jika ditulis menjadi:

$900+70+2=972$.

Metode perkalian dengan metode bersusun di atas sering membuat siswa lupa karena hasil kalinya mesti disimpan jika hasilnya lebih dari dua angka (mengandung nilai puluhan), selain itu siswa sering lupa memperhatikan penulisan letak bilangan, dimana bilangan mestinya ditulis agak menjorok ke kiri pada baris bilangan berikutnya (tidak sejajar dengan baris sebelumnya). Jika prosedurnya salah, misal diletakkan sejajar setiap barisnya, maka akan didapat hasil perkalian yang keliru.

Metode alternatif berikut adalah metode perkalian bilangan dengan menggunakan metode latis. Metode ini lebih menyenangkan siswa, karena dibuat dalam bentuk tabel dan tidak menerapkan konsep penyimpanan bilangan (karena langkah simpan-menyimpan pada perkalian bilangan sering membuat siswa lupa dan kadang-kadang jadi salah konsep (Nugent, 2007). Lebih detail metode latis dapat dijelaskan sebagai berikut:

Contoh 1

$23 \times 12=\ldots .$.

Langkah-langkahnya :

a. Buat tabel $2 \times 2=4$ (karena bilangan yang akan dikalikan adalah bilangan yang memuat dua angka dengan bilangan yang memuat dua angka).

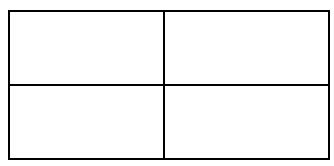


Dharma Raflesia : Jurnal Ilmiah Pengembangan dan Penerapan IPTEKS 18 (1) 2020

b. Tulis bilangan yang akan dikalikan

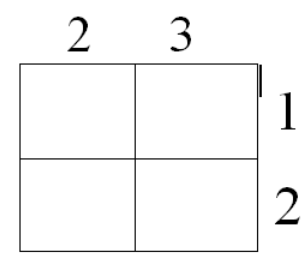

c. Lalu buat diagonal pada tabel seperti berikut:

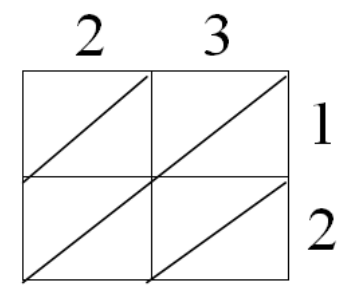

d. Kalikan setiap bilangan, dan letakkan pada tabel yang bersesuaian, jika hasil kalinya hanya memuat 1 angka (satuan saja), maka letakkan angka nol di sebelah kirinya.

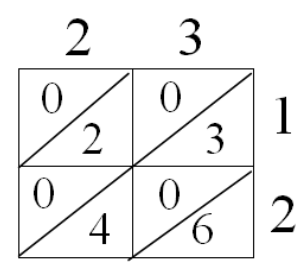

e. Jumlahkan setiap bilangan pada masing-masing diagonal

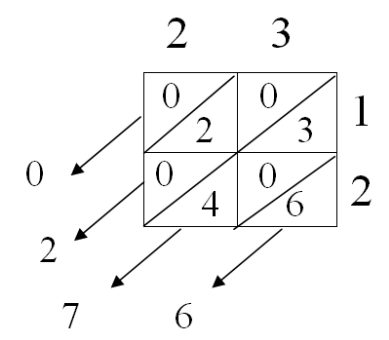

Sehingga diperoleh: $23 \times 12=276$

Contoh 2. $45 \times 24=\ldots$

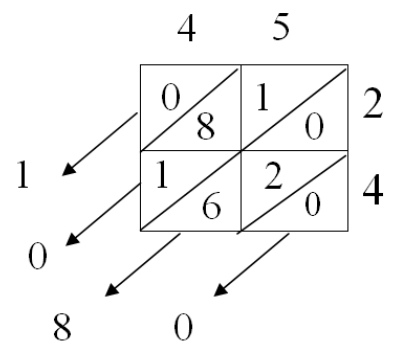


Dharma Raflesia : Jurnal Ilmiah Pengembangan dan Penerapan IPTEKS 18 (1) 2020

Untuk diagonal yang penjumlahan bilangannya lebih dari atau sama dengan sepuluh, hanya ditulis bilangan satuannya, sedangkan nilai tempat puluhan ditambahkan pada bilangan (hasil penjumlahan diagonal sebelah kiri).

Pada contoh 2 di atas, didapat jumlah diagonal kedua $(1+8+1=10)$, sehingga hanya ditulis angka satuannya saja, yaitu angka 0 , sedangkan angka 1 pada bilangan 10 tersebut (nilai puluhannya) ditambahkan pada bilangan hasil penjumlahan diagonal sebelah kiri yaitu $1+0=1$, dengan demikian $45 \times 24=1080$.

Pengetahuan guru-guru SD N 10 Pondok Kelapa Kabupaten Bengkulu Tengah sebelum kegiatan dilaksanakan yakni tentang berbagai metode operasi perkalian matematika untuk SD masih relatif kurang. Mayoritas guru-guru hanya mengetahui metode perkalian bersusun yang sudah lazim digunakan di sekolah dasar. Tak satu pun guru yang mengetahui metode perkalian alternatif yang lain selain metode perkalian bersusun, seperti misalnya metode perkalian latis, metode perkalian garis, metode jarimatika dan lain sebagainya. Menurut mereka, mendengar nama metode perkalian tersebut pun belum pernah, apalagi menggunakannya dalam proses pembelajaran.

Banyak guru-guru yang antusias bertanya tentang metode perkalian alternatif selain metode bersusun ini. Respon mereka sangat baik, dan motivasi untuk menerapkannya di sekolah mereka sangat tinggi. Berdasarkan hasil angket yang diberikan oleh tim pelaksana bahwa menurut para perserta pelatihan, kegiatan ini sangat bermanfaat dan metode perkalian latis yang disosialisasikan sangat menarik dan persepsi mereka jika nanti diterapkan di kelas akan sangat menyenangkan khususnya bagi siswa yang mengalami kesulitan dalam mempelajari metode operasi perkalian bersusun.

Hal ini sesuai dengan apa yang dikemukakan oleh Nugent (2007) yang mengatakan bahwa metode perkalian latis ini lebih menyenangkan siswa, karena dibuat dalam bentuk tabel dan tidak menerapkan konsep penyimpanan bilangan (karena langkah simpan-menyimpan pada perkalian bilangan sering membuat siswa lupa dan kadang-kadang jadi salah konsep). Sedangkan pada metode perkalian latis juga seolah-olah mengajak siswa bermain teka teki silang yaitu mengisi tabel-tabel kosong yang disediakan.

Selanjutnya Suparman (1997) mengatakan bahwa strategi pembelajaran mengandung empat komponen utama, yaitu: urutan kegiatan pembelajaran, metode 
Dharma Raflesia : Jurnal Ilmiah Pengembangan dan Penerapan IPTEKS 18 (1) 2020

pembelajaran, media pembelajaran, dan waktu yang digunakan dalam proses pembelajaran. Oleh karena itu, untuk dapat merencanakan dan melaksanakan kegiatan pembelajaran yang sebaik-baiknya tentulah sangat tergantung dari strategi yang akan dipilih guru untuk digunakan dalam pembelajaran.

Seperti diketahui bahwa tujuan khusus pembelajaran matematika di Sekolah Dasar adalah agar siswa memahami dan menggunakan sifat-sifat operasi hitung khususnya operasi hitung perkalian dua angka dengan dua angka yang merupakan kompetensi dasar yang baru bagi siswa kelas III sehingga kemampuan dasar melakukan operasi hitung perkalian dikuasai oleh siswa. Dengan demikian guru perlu mencari strategi pembelajaran alternatif metode operasi perkalian yang menyenangkan, seperti metode perkalian latis.

Metode perkalian Latis merupakan metode perkalian yang disajikan dalam bentuk tabel yang memuat hasil perkalian. Hasil perkalian dua bilangan ditempatkan dalam tabel yang disusun berdasarkan satuan, puluhan, ratusan dan seterusnya. Metode latis sangat berbeda sekali dengan metode perkalian bersusun, dimana nilai sudah ditempatkan dalam kotak tertentu sehingga mengurangi tingkat kesalahan siswa dalam operasi perkalian bilangan asli.

Guru-guru SD N 10 Pondok Kelapa pada awalnya semua belum memiliki pengetahuan tentang metode perkalian alternatif selain metode perkalian bersusun yang dapat diterapkan pada mata pelajaran matematika terutama pada materi operasi perkalian bilangan asli. Para guru belum memiliki pengetahuan bagaimana cara menerapkan metode perkalian latis pada penyelesaiaan soal-soal perkalian bilangan asli, khususnya bilangan ratusan, ribuan dan seterusnya. Mereka juga kurang memiliki motivasi untuk mencoba strategi pembelajaran baru. Misalnya mereka sudah terbiasa dengan mengajarkan siswa menggunakan metode perkalian bersusun untuk memberikan konsep operasi perkalian dasar, sehingga guru belum pernah memberikan ide untuk mencari metode atau strategi pembelajaran yang lain yang lebih menyenangkan bagi siswa SD. Seperti kita ketahui bahwa bahwa pembelajaran matematika di sekolah dasar berbeda dengan pembelajaran matematika di SMP dan SMA. Pembelajaran matematika di Sekolah Dasar menggunakan metode spiral, bertahap, menggunakan metode induktif, menganut kebenaran konsistensi serta bermakna (Suherman, et al, 2006). 
Dharma Raflesia : Jurnal Ilmiah Pengembangan dan Penerapan IPTEKS 18 (1) 2020

Setelah workshop/seminar dilaksanakan dan setelah selesai kegiatan praktek penyelesaian soal-soal tentang operasi perkalian bilangan asli dengan menggunakan metode perkalian latis, maka $100 \%$ guru sudah mengetahui dan memahami bagaimana cara menerapkan metode perkalian latis yang menyenangkan untuk menyelesaikan soal-soal perkalian bilangan. Secara umum, respon guru terhadap kegiatan ini sangat baik (positif) dan pengetahuan mereka tentang metode perkalian latis sebagai metode perkalian alternatif menjadi lebih meningkat.
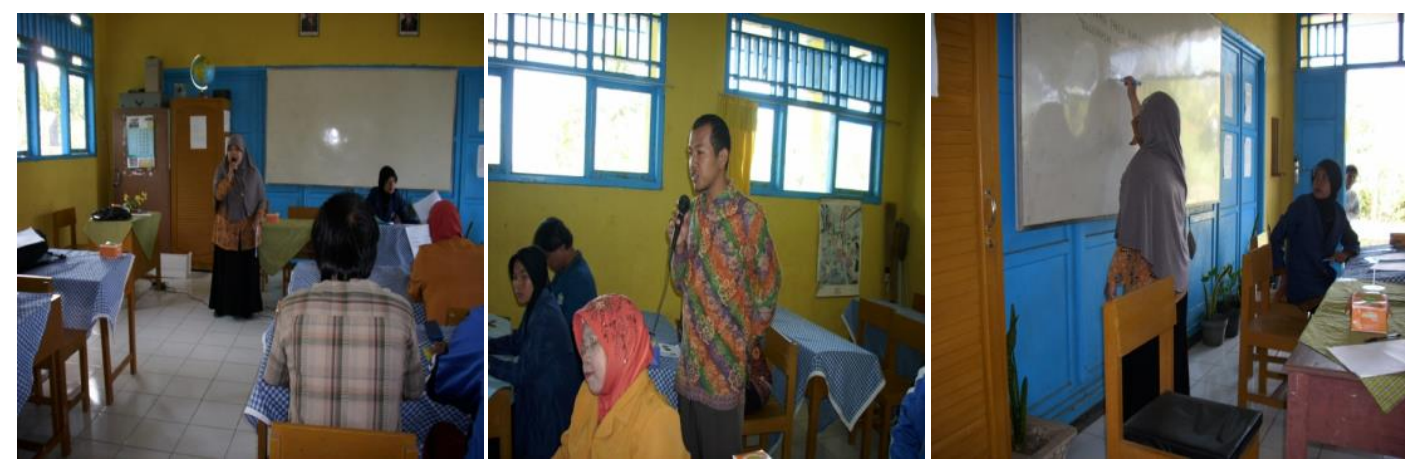

Gambar 1. Memperkenalkan metode pembelajaran

\section{KESIMPULAN DAN SARAN}

1. Kegiatan sosialisasi pengenalan metode Latis sebagai metode perkalian alternatif kepada para guru SD Negeri di Kec Pondok Kelapa, Kab Bengkulu Tengah berhasil dilaksanakan.

2. Kemampuan dan keterampilan guru-guru SD Negeri Di Kecamatan Pondok Kelapa Kabupaten Bengkulu Tengah dalam menerapkan metode ini sanagt baik, 100\% 100\% guru sudah mampu menerapkan pada berbagai penyelesaian kasus soal-soal perkalian bilangan.

Berdasarkan hasil kegiatan pelatihan, maka disarankan kepada pihak-pihak yang terkait dan berkepentingan dengan masalah pembelajaran matematika, yaitu sebagai berikut:

1. Sosialisasi maupun pelatihan tentang metode pembelajaran alternatif yang menyenangkan untuk materi yang lain kepada para guru maupun siswa pada jenjang yang lebih tinggi perlu dilakukan. 
Dharma Raflesia : Jurnal Ilmiah Pengembangan dan Penerapan IPTEKS 18 (1) 2020

2. Institusi pendidikan, baik SD, SMP, maupun SMA perlu menyusun Rencana Pembelajaran yang berorientasi pembelajaran yang menyenangkan khususnya mata pelajaran matematika yang bersifat abstrak.

\section{DAFTAR PUSTAKA}

Lynn W, Bellevue, NE. 2011. An Introduction to Various Multiplication Strategies. Washington. USA. Merrill Prentice Hall.

Marifah, H. 2014. Meningkatkan Hasil Belajar Operasi Hitung Perkalian Bersusun Ke Bawah dengan Media Papan Napier pada Pembelajaran Matematika bagi Siswa Kelas III SD Dapuan Surabaya. Universitas Negeri Surabaya. PGSD FKIP.

Marzuki. 2011. Meningkatkan Prestasi Belajar Perkalian Bersusun Menggunakan Model Kooperatif Tipe TAI pada Siswa Kelas IV SD Negeri 3 Meurah Dua. Lentera: Vol.11, No.2, Agustus 2011. Bireuen.

Muhsetyo, G et al. 2007. Pembelajaran Matematika SD. Jakarta: Universitas Terbuka. Nugent, PM. 2007. Lattice multiplication in a preservice classroom. Mathematics Teaching in the Middle School, 13(2), 110-113.

Yensy, NA. 2017. Pelatihan PAKEM Matematika SD dengan menggunakan kotak KPK dan FPB bagi Guru SD di Kecamatan Pondok Kelapa. Jurnal Ilmiah Pengabdian. DHARMA RAFLESIA, LPPM UNIB, ISSN:1693-8046, Tahun XV Nomor 1 Juni 2017. Universitas Bengkulu.

Yensy, NA. 2018. Pelatihan Pembelajaran Aktif Berbantuan Blok Aljabar bagi Guru SMP N 1 Pondok Kelapa. Jurnal Ilmiah Pengabdian. DHARMA RAFLESIA, LPPM UNIB, ISSN:1693-8046, Tahun XVI Nomor 1 Juni 2018. Universitas Bengkulu.

Yensy, NA. 2019. Sosialisasi Active Learning Matematika melalui Permainan kartu bagi Guru-guru SD N 69 Kota Bengkulu. Jurnal Ilmiah Pengabdian. DHARMA RAFLESIA, LPPM UNIB, ISSN:1693-8046, Tahun XVII Nomor 1 Juni 2019. Universitas Bengkulu.

Suherman, Erman,et al 2006. Strategi Pembelajaran Matematika Kontemporer.

Bandung : Jica Jurusan Pendidikan Matematika FMIPA Universitas Pendidikan Indinesia.

Susanto, A. 2013. Teori Belajar dan Pembelajaran. Jakarta: Kencana Prenada Media Group. 